\title{
Penyemaian Sikap Hidup Damai di Sekolah: Tinjauan Pendidikan Perdamaian dan Multi-Dimensi Kurikulum
}

\author{
Nurwanto, Wahdan Najib Habiby \\ nurwanto@umy.ac.id,wnh122@ums.ac.id \\ Fakultas Agama Islam, Universitas Muhammadiyah Yogyakarta \\ Fakultas Keguruan dan Ilmu Pendidikan, Universitas Muhammadiyah Surakarta \\ Nurturance of Peaceful Life Attitudes in Schools: \\ Peace Education and Multidimensional Curriculum Perspectives
}

\begin{abstract}
This article aims to theoretically elaborate a strategy of disseminating peace through peace education and curriculum construction integrated with schooling experiences. Violent behaviors committed by several groups of students have become a reason of why peace dissemination in schools is paramount. The existing curriculum merely concerning its teaching and learning documents has been considered as both insufficient for integrated peace education and inadequate to transform behaviors for peace. This study was conducted through library research on books and journals informing peace education and multidimensional curriculum. This study finds that peace education, which includes building capacities to reduce violence and to sustain cooperative and equal relationships, can be constructed in schooling processes. Moreover, the learning stages need to incorporate various dimensions of peace contents or experiences as planned, acted, evaluated, learned and hidden within the classroom and school interactions. It is suggested that the multi-dimensional curriculum is likely to cohere with a comprehensive school framework for peaceful school life.
\end{abstract}

Keywords:Violence, Peace, Curriculum Dimensions, Hidden Curriculum

\section{Article Info}

Received date: 17 September 2019 Revised date: 20 Desember 2019 Accepted date: 21 Januari 2020

\section{PENDAHULUAN}

Kekerasan di sekolah telah menjadi isu global. UNICEF (2017) menyajikan data bahwa hampir separuh anak usia 13-15 tahun pernah mengalami kekerasan di dalam dan luar sekolah. Di Indonesia, kurang lebih $84 \%$ anak mengalami kekerasan dalam skala dan kondisi yang beragam (Rakhmat \& Tarahita, 2018). Sedangkan Yogyakarta sebagai contoh lokal telah dikejutkan dengan fenomena 'klithih' (Jawa) yakni tindakan melukai orang lain dengan tanpa alasan yang jelas (Kedaulatan Rakyat 29/01/2018). Sementara itu, tawuran antar pelajar di Yogyakarta dari tahun 2014 hingga 2017 telah menyebabkan 6 remaja terbunuh (Muryanto, 2017). Perkelahian antar-remaja terjadi mulai dari antarindividu, antar-kelompok dari sekolah yang berbeda hingga lintas-sekolah. Fenomena ini secara umum melibatkan kelompok pelajar laki-laki yang meluas di sejumlah kota di Indonesia dengan modus dan dampak yang bervariasi (Kadir, 2012; Nilan, Demartoto, \& Wibowo, 2011). Bahkan menurut data BPS (2014), dalam hal kekerasan pelajar, jumlah konflik massal per kelurahan di Indonesia menunjukkan angka yang memprihatinkan karena melibatkan pelajar/mahasiswa yang mencapai angka kontribusi sebesar 3,5\%, atau sekitar 58 dari 1.655 jumlah desa/kelurahan yang ada. Pendek kata, kekerasan menjadi tantangan serius bagi publik dan lembaga pendidikan.

Ada argumen bahwa kekerasan yang dilakukan oleh pelajar merupakan bagian dari proses pencarian 'jati diri' sehingga seolah-olah perlu ada permakluman. Namun, dalam banyak kasus, dampak dari kekerasan tersebut cukup serius, baik bagi korban maupun bagi keamanan masyarakat. Status kekerasan remaja dapat dikategorikan sebagai kriminal karena, misalnya, melukai atau bahkan menghilangkan nyawa seseorang (Yasin \& Perdana, 2014). Penyebab dari kejadian seperti ini perlu ditelaah, termasuk faktor-faktor eksternal dan internal sekolah yang berkontribusi terhadap pikiran, sikap dan perilaku kekerasan pelajar. Sebagaimana dikatakan Standish (2015), kultur suatu lokasi, termasuk sekolah, dapat menjadi bibit perilaku kekerasan, misalnya kebiasaan mengejek teman lainnya. 
Atas dasar ini, pengembangan kultur dan implementasi kurikulum sekolah yang memproduksi pikiran dan sikap damai perlu terus-menerus dilakukan. Tulisan ini difokuskan pada kepentingan teoretik tentang bagaimana kulturisasi keramahan dan perdamaian hidup dapat diwujudkan melalui kanal kurikulum yang bersifat multidimensional di tengah arus dan tantangan kekerasan pelajar yang muncul di berbagai wilayah, misalnya Jakarta (Saad, 2003), Yogyakarta (Kadir, 2012), Surakarta (Nilan et al., 2011) dan Purworejo (Djamal, 2016).

\section{KAJIAN PUSTAKA}

Studi terdahulu tentang kekerasan di lingkungan sekolah telah dilakukan oleh sejumlah akademisi. Harber (2008) mengidentifikasi beberapa bentuk kekerasan di sekolah Afrika Selatan seperti kekerasan fisik, kekerasan seksual, kekerasan rasial dan kekerasan psikis berupa pressure mental untuk meraih skor tinggi dalam ujian nasional. Dia juga menunjukkan bentuk kekerasan fisik lainnya di sekolah seperti 'militerisasi' (Harber, 2002). Lebih lanjut, Davies (2005) menemukan adanya bias gender dalam kekerasan, seperti anggapan wajar terhadap agresivitas siswa laki-laki dibandingkan anggapan terhadap perempuan. Dalam konteks Indonesia, Djamal (2016) menemukan ragam kekerasan baik yang bersifat fisik (terlihat), kombinatif antara verbal dan fisik, struktural, simbolik serta kekerasan yang berdampak kompleks bagi kehidupan seseorang seperti pemerkosaan. Semua kategori kekerasan ini, oleh Fell dalam Hicks (1988), dibagi menjadi dua garis besar, yakni: kekerasan yang tampak/langsung (beberapa hal bersifat fisik) dan kekerasan yang tertutup/tidak langsung/kultural/struktural. Berbagai kajian di atas menyadarkan publik bahwa sekolah yang sebenarnya dicita-citakan sebagai arena penyemaian cara hidup damai dapat secara potensial atau faktual menjadi lokus sikap dan tindakan kekerasan, baik yang tampak maupun tersembunyi; terencana dan sistematis, ataupun insidental.

Terlepas dari ragam kekerasan di sekolah, Davies (2009) dalam bukunya Educating against Extremism tetap optimis bahwa sekolah dapat menjadi harapan untuk perdamaian jika siswa dididik untuk well-informed (memahami dengan baik) tentang makna penting perdamaian dan betapa bahayanya perilaku yang melampui batas yang dilegitimasi kekerasan (extremism). Bagi Davies, siswa juga perlu dilatih untuk berfikir dan bertindak kritis sehingga tidak mengimitasi dan mengadopsi ideologi kekerasan yang bebas di media publik. Berfikir kritis yang dimaksud adalah kemampuan menelaah, menimbang dan menujukkan kelebihan serta kekurangan informasi yang diterima. Ekspektasi akademisi seperti Davies bahwa sekolah perlu menekankan narasi hidup damai sebenarnya sudah dikaji oleh beberapa peneliti. Pembelajaran keagamaan di sekolah, secara formal sebenarnya sudah menawarkan bahan-bahan yang cukup informatif tentang sikap hidup damai, toleransi dan kerjasama (N. Nurwanto, Azhar, Marsudi, \& Ismail, 2015). Namun demikian, menurut Ardizzone (2001), pembelajaran di sekolah belum menempatkan pendidikan perdamaian sebagai prioritas utama melalui proses pedagogis yang utuh dan terpadu. Ini disebabkan kurikulumnya terbebani dengan tuntutan materi yang banyak (content-oriented) dan mengutamakan hafalan untuk ujian sekolah atau nasional sehingga transformasi sikap sosial cukup terabaikan. Sejalan dengan ini, Harber and Sakade (2009) serta Arweck and Nesbitt (2008) menemukan bahwa implementasi program pendidikan nilai yang berbasis keagamaan secara non-formal misalnya melalui training, memiliki pengaruh yang lebih baik dibandingkan dengan pembelajaran formal. Dengan demikian, temuan ini menjadi tantangan bagi pendidikan formal untuk menempatkan pendidikan nilai seperti perdamaian sebagai prioritas dan dikombinasikan dengan program non-formal atau ektra-kurikuler lainnya. Oleh karena itu, Lewsader and Myers-Walls (2017) merumuskan kurikulum hidup damai dalam kehidupan sekolah yang bersifat integratif. Integrasi yang dimaksud adalah bahwa nilai-nilai perdamaian menyatu dalam setiap mata pelajaran dan/atau dalam interaksi langsung keseharian di sekolah (school life). Dengan kata lain, penyemaian hidup moderat dan damai perlu dimulai dari sistem pembelajaran terpadu dalam lingkup keseharian di sekolah (Hergianasari, 2019).

Dari kajian sebelumnya tersebut, terdapat ruang diskusi tentang model kurikulum integratif yang diperlukan dalam sistem persekolahan. Selanjutnya, artikel ini dimaksudkan untuk menawarkan pengarus-utamaan sikap damai di sekolah dengan tidak dibatasi hanya pada kurikulum resmi/terencana, sebagaimana yang termaktub dalam buku atau bahan ajar tetapi sistem sekolah itu sendiri merupakan dimensi rencana dan aksi kurikulum itu sendiri secara berkelanjutan. Artikel ini hendak mengupas makna penting kurikulum yang bersifat multidimensional dalam sistem persekolahan. 


\section{METODE PENELITIAN}

Tulisan ini merupakan kajian pustaka (library research) tentang ruang lingkup pendidikan perdamaian yang dapat dikonstruk dalam kehidupan sekolah. Asumsi yang dibangun adalah bahwa sekolah dapat mengonstruk kurikulumnya secara lebih terintegrasi. Oleh karena itu, sumber utama (primary source) teoretisasinya adalah dari Pollard, Black-Hawkins, Cliff-Hodges, Dudley, and James (2014) tentang multi-dimensi kurikulum dan Kelly (2009) tentang kurikulum yang direncanakan dan kurikulum yang dipraktekkan. Pustaka yang ditelaah dalam kajian ini adalah buku-buku, artikel-artikel jurnal dan sumber data online terutama website media massa, yang berkaitan dengan kurikulum dan pendidikan perdamaian. Data-data pustaka yang terkumpul kemudian dianalisis dengan melalui beberapa tahap. Pertama, tahap penyusunan tema/kategori. Konsep pendidikan perdamaian dikategorikan ke dalam definisi/ruang lingkup pendidikan perdamaian. Sementara itu, konsep multidimensi kurikulum diuraikan ke dalam tema/ruang lingkup kurikulum yang direncanakan, diimplementasikan, diujikan, dikuasai dan tersembunyi dalam sistem sekolah. Berikutnya, hasil analisis disajikan secara naratif dan analitis mengenai arah penyemaian hidup damai dalam dimensi-dimensi kurikulum yang bersifat integratif dan berkelanjutan.

\section{HASIL PENELITIAN DAN PEMBAHASAN}

Bagian ini menyajikan temuan atau hasil penelitian yang meliputi aspek-aspek pendidikan perdamaian yang perlu diadopsi dari berbagai ide dan pengalaman di sejumlah negara dan refleksi sosiologis atas persoalan konflik sosial di Indonesia. Selanjutnya, bagian kedua menyajikan temuan dan bahasan tentang ragam dimensi kurikulum yang perlu dikembangkan dalam penanaman sikap hidup damai di sekolah.

\section{Pendidikan Perdamaian}

Setelah Perang Dunia II, pembangunan atau pendidikan perdamaian telah menjadi program di banyak negara. Secara konseptual, Harris and Morrison (2012) menjelaskan bahwa pendidikan perdamaian merupakan komitmen terhadap hidup damai dan mengatasi budaya kekerasan yang muncul dalam situasi pendidikan. Selanjutnya, Bar-Tal (2002) mengelaborasi bahwa pendidikan perdamaian sangat bervariasi di sejumlah kawasan karena dipengaruhi oleh tantangan nyata yang dihadapinya. Menurutnya, Australia menekankan pendidikan perdamaian pada upaya mengatasi etnosentrisme, loyalitas ekstrem terhadap kelompok serta, di sisi yang lain, mempromosikan keragaman budaya, anti senjata nuklir dan resolusi konflik. Sementara itu, Amerika memprioritaskan pada upaya mengatasi prasangka kelompok (group prejudice), kekerasan dan masalah lingkungan. Namun, sebaliknya, dengan naiknya Donald Trump sebagai Presiden AS mulai 2017, beberapa kebijakan politiknya justru berlawanan dengan semangat anti-rasialisme. Oleh karena itu, kebijakan politik suatu negara yang rasialis sangat dipengaruhi oleh penguasanya meskipun, pada saat yang sama, gerakan-gerakan sosial berkomitmen untuk perdamaian dunia. Sebagai contoh lainnya, pernyataan resmi Gedung Putih di bawah Trump yang menyatakan bahwa Yerusalem dideklarasikan sebagai ibukota Israel ternyata ditolak oleh mayoritas anggota Dewan Keamanan PBB karena isinya berdampak buruk bagi langkah menuju perdamaian Palestina-Israel. Dengan melihat kasus seperti ini, penegakan perdamaian sangat tergantung juga pada penentu kebijakan negara, di samping keyakinan, nilai-nilai dan narasi kultural tentang hidup bersama.

Secara konseptual, Bar-Tal selanjutnya menyatakan bahwa tujuan pendidikan perdamaian adalah untuk mengurangi atau membasmi berbagai 'penyakit' manusia mulai dari ketidakadilan, prasangka kelompok, intoleransi, perusakan lingkungan, konflik dengan kekerasan, perang dan kejahatan lainnya dalam rangka mewujudkan dunia yang penuh dengan keadilan, kesamaan, toleransi, HAM, kualitas lingkungan, perdamaian dan wujud kehidupan yang positif lainnya (Bar-Tal, 2002). Pandangan ini sejalan dengan konseptualisasi De Rivera (2009) bahwa pendidikan perdamaian itu dapat ditekankan pada 'negative peace' yang mencegah timbulnya konflik, kekerasan dan intimidasi dan, di lain pihak, 'positive peace' yang menaruh perhatian pada pembangunan keadilan, lingkungan hidup yang berkelanjutan dan kerjasama sosial di berbagai lini kehidupan. Merujuk pada tujuan pendidikan perdamaian tersebut, dengan menggunakan konsep Al-Qur'an, ada area amar ma'ruf atau perintah kebaikan (sejalan dengan positive peace) berupa penciptaan kerjasama dan keadilan di satu sisi, dan nahi munkar atau pencegahan keburukan (sejalan dengan negative peace) seperti kekerasan dan 
ancaman. Atas dasar ini, berbagai ajaran normatif keagamaan sebenarnya dapat diuraikan dan sejalan dengan konsensus moral tentang hidup damai.

Kajian Khan (2009) dan Köylü (2004) secara meyakinkan bahwa baik dari sumber normatif maupun historis, agama seperti Islam cenderung pada perdamaian, bukan kekerasan, sesuai dengan makna Islam (salam: damai). Keduanya sepakat bahwa jalan perang adalah emergency exit (jalan keluar darurat) ketika pihak Muslim diserang terlebih dahulu dan bermaksud mempertahankan diri. Oleh karena itu, semangat damai, bukan untuk berperang, menurut Khan, adalah esensi Islam itu sendiri. Dengan menggunakan konsep Fox (2014), ajaran asal agama seperti Islam adalah pasifisme absolut, tetapi dalam kondisi nyata, perang adalah pilihan terburuk (moderate pacifism). Sementara itu, telaah Amin membuka cakrawala bahwa tafsir atas Al-Qur'an memiliki dampak yang penting tentang bagaimana Muslim merespons perbedaan termasuk persinggungan dan konflik antara Muslim dan NonMuslim. Di antara ayat yang sering disalah-pahami adalah QS. Al-Anfal (8) ayat 60, terutama lafazh 'turhibuna' (menggetarkan) untuk membenarkan tindakan terorisme (to strike terror) dalam bentuk gerakan mengancam dan merusak fasilitas publik atas nama agama. Bagi Amin (2015), ayat ini sebenarnya panggilan universal bagi umat Islam agar memiliki pengaruh intelektual, pendidikan, ekonomi dan militer. Misinterpretasi atas ajaran agama berupa terorisme sebenarnya fallacy dalam pengetahuan keagamaan dengan menjadikan agama sebagai komoditas politik dan kepentingan ekonomi semata. Atas dasar ini, Purwawidada (2014) menyatakan bahwa pendidikan agama dapat berpotensi dan secara aktual menjadi alat penyemaian kepribadian yang pro-kekerasan dan antipati terhadap keragaman, apabila pemahaman yang komprehensif atas ajaran agama tidak terkelola dengan memadai. Oleh karena itu, penyemaian nilai-nilai yang humanis dan toleran melalui pendidikan agama menjadi tanggung jawab, baik sekolah, keluarga maupun masyarakat termasuk tempat-tempat peribadatan.

Sementara itu, Al Qurtuby (2016) melakukan telaah atas pengaruh pemahaman doktrin agama. Telaahnya tentang konflik berdarah di Ambon secara khusus atau Maluku pada umumnya, dengan tanpa mengabaikan faktor historis, politik, ekonomi dan militer sebagai akar konflik, menunjukkan bahwa tafsir atas ajaran agama dari pihak Muslim dan Kristen berkontribusi, baik untuk konflik atau damai. Menurutnya, sebagian Muslim di Maluku digerakkan oleh interpretasinya atas QS. Al-Baqarah (2) ayat 120 dan 190-193, yang memahami jihad berupa perang merupakan pembelaan atas umat Islam yang terdesak oleh kaum penentang serta sebagai reaksi atas informasi bahwa pihak Kristen akan menjadikan Ambon sebagai wilayah Kristen (Al Qurtuby, 2016). Di sisi yang lain, sejumlah umat Kristen lebih memilih Perjanjian Lama untuk menganalogikan perang di Ambon sebagai perjuangan Nabi Daud melawan Goliat atau setan. Pihak Kristen merepresentasikan dirinya sebagai golongan Nabi Daud sedangkan pihak Muslim digolongkan sebagai pendukung Goliat. Pada saat yang sama, sebagian pemimpin Gereja terutama Protestan menghindari penggunaan ayat-ayat Perjanjian Baru sebagai dasar teologis untuk berinteraksi, apalagi dalam situasi perang, karena di dalamnya secara dominan mengajarkan cinta dan persaudaraan (Al Qurtuby, 2016).

Dalam telaahnya, Al-Qurtuby menunjukan dinamika dalam memilih jalan damai dalam situasi perang. Salah seorang tokoh kunci Muslim Ambon yang diwawancara menyatakan bahwa ia tidak sepakat dengan tokoh Laskar Jihad yang berkeyakinan bahwa dengan posisi umat Islam yang hampir menang maka tiba saatnya kaum Kristen disingkirkan dari tanah Maluku. Sebaliknya, tokoh kunci muslim Ambon justeru menyatakan bahwa ia menerima ajakan pihak Kristen untuk berdialog karena mereka berkeinginan untuk mengakhiri perang. Dengan mendasarkan pada Al-Qur'an, ia berpendapat bahwa kaum Muslim tidak dapat melanjutkan perang ketika pihak musuh telah menyerah dan berniat untuk mencapai perdamaian (Al Qurtuby, 2016). Jalan damai ini merupakan pilihan yang dapat dikategorikan 'jihad' dengan dianalogikan sebagai 'jihad besar' berupa melawan hawa nafsu sebagaimana diyatakan dalam Hadis (sumber hukum kedua). Terlepas dari ini semua, perbedaan tafsir atas doktrin kitab suci tentang kapan perang diawali atau diakhiri menjadi momentum penting dalam sejarah komunitas beragama. Sebagaimana diketahui, beberapa pihak Kristen yang menyetujui Malino II lebih memilih ajaran dalam Perjanjian Baru yang menekankan ajaran cinta, ampunan dan pesan-pesan damai sedangkan sebagian pihak Kristen yang berniat melanjutkan perang menggunakan heroisme perang dalam Perjanjian lama (Al Qurtuby, 2016). Temuan ini mengindikasikan bahwa bahwa seleksi atas pemahaman doktrin agama dapat menjadi dasar untuk menuju damai atau konflik.

Riset di atas paling tidak menginspirasi pendidikan perdamaian bahwa mengakhiri konflik dan perang bukan sekedar urusan negosiasi politik dan militer. Namun demikian, di dalamnya terdapat 
keyakinan atas aspek normatif keagamaan dan aspek psikologis tentang mengatasi egoisme personal (Mirbagheri, 2012) dan kelompok. Pendidikan perdamaian juga melatih seseorang untuk keluar dari zona kekerasan, kedengkian dan balas-dendam menuju zona saling mendengar, mengampuni dan, secara pribadi atau kolektif, menapaki 'jalan terjal' menuju kerjasama dan saling memahami. Dengan demikian, pendidikan perdamaian meliputi unsur mencegah dan mengatasi kebencian, kekerasan dan konflik yang disebut dengan negative peace; dan unsur membangun toleransi dan kerjasama yang berkesinambungan di tengah komunitas dan masyarakat yang disebut dengan positive peace.

\section{Multi-Dimensi Kurikulum Perdamaian}

Telaah atas keragaman konsep kurikulum yang dikaitkan dengan perdamaian cukup penting. Sebagaimana diketahui, menurut Alkin (1992), pada mulanya kurikulum hanya dipahami sebagai bahan ajar yang disiapkan sekolah. Sementara itu, Ralph Tyler menggunakan istilah 'pengalaman' (experience) daripada 'materi' (content) (Stanley, 2009), yang mengindikasikan bahwa apa yang diajarkan bukanlah sekedar materi yang sudah disiapkan dalam bahan ajar dan buku teks, tetapi juga pengalaman-pengalaman nyata yang dialami peserta didik, guru dan orang lain yang dijadikan sebagai sumber belajar (konstruktivistik). Dalam dekade terakhir ini, perspektif yang lebih komprehensif tentang kurikulum hadir, di antaranya dalam kajian Pollard et al. (2014). Menurut mereka, pemahaman tentang kurikulum saat ini perlu merujuk pada kurikulum dalam keragaman dimensi, yang meliputi apa yang direncanakan secara formal (planned), apa yang diaktualisasikan dalam proses pembelajaran (observed), apa yang diujikan (assessed), apa yang dapat dikuasai oleh siswa (learned) serta apa yang tersembunyi (hidden). Kelima dimensi ini bisa saja koheren namun bisa pula tidak saling mendukung. Dampak dari cakupan luas kurikulum ini adalah bahwa interaksi atas sumber-sumber belajar dengan rekayasa sistem dan kultur sekolah sebagai arena penyemaian hidup damai menjadi semakin terbuka. Kekuatannya adalah bahwa pembinaan hidup damai muncul dari berbagai lini sekolah dan, pada saat yang sama, kelemahannya adalah bahwa proses edukasi hidup damai memerlukan energi ekstra dari keseluruhan sistem pendidikan.

\section{Kurikulum Resmi (Planned)}

Sejauh ini, kurikulum resmi dapat disiapkan dan direncanakan oleh Pemerintah, lembaga resmi yang ditunjuk, atau pihak sekolah. Secara teoretik, Kelly (2009) memaparkan Schon's model yang membagi tiga model pengembangan kurikulum yakni centre-periphery, proliferation of centres dan shifting centres. Model pertama menjelaskan bahwa kurikulum disusun oleh pemerintah; model kedua mengarahkan kurikulum agar disusun oleh lembaga di bawah pemerintah yang langsung berinteraksi dengan sekolah dan mengembangkan prinsip-prinsip dasar pendidikan yang dicanangkan pemerintah; sedangkan model ketiga menempatkan sekolah sebagai pusat perencanaan dan pengembangan kurikulum. Model 1 mencerminkan pola instruksi (top down), model 2 mencerminkan desentralisasi dan model 3 memberkuat basis otonomi sekolah dan guru untuk mengembangkan kurikulum (demokratisasi kurikulum). Bila hal ini dikaitkan dengan arus pendidikan perdamaian maka semua lini manajemen pendidikan tersebut dapat berperan dalam memperkuat visi dan misi hidup damai melalui lembaga pendidikan.

Prioritas pada pembangunan karakter peserta didik telah digulirkan dalam kurikulum di Indonesia. Kurikulum 2013 yang saat ini berlaku merinci Standar Kompetensi Lulusan (SKL) ke dalam Kompetensi Inti (KI) untuk tiap jenjang yakni: KI-1 tentang sikap spiritual, KI-2 tentang sikap sosial, KI-3 tentang pengetahuan dan KI-4 tentang keterampilan. Adapun sikap yang ditonjolkan di antaranya adalah cinta damai, kasih sayang, menghargai orang lain, kerjasama (Permendikbud No. 64 Tahun 2013). Ini sejalan pula dengan 18 karakter siswa yang dikembangkan oleh Pemerintah yakni: religius, jujur, toleransi, toleransi, disiplin, kerja keras, kreatif, mandiri, demokratis, rasa ingin tahu, semangat kebangsaan, cinta tanah air, menghargai prestasi, komunikatif/bersahabat, cinta damai, gemar membaca, peduli lingkungan, peduli sosial, dan tanggung jawab. Selain arus kebijakan di atas, para pegiat Living Values Education (LVE) memopulerkan 12 nilai yang meliputi: kedamaian, penghargaan, kasih sayang, toleransi, kejujuran, kerendahan hati, kerjasama, kebahagiaan, tanggung jawab, kesederhanaan, kebebasan dan persatuan (Munawar-Rachman \& Shofan, 2015). Dengan demikian, secara teoretis, kurikulum resmi, baik yang digulirkan oleh pemerintah maupun komunitas sudah sarat dengan karakter damai dan nilai-nilai pro-sosial lainnya. 
Namun demikian, ruang lingkup kurikulum resmi bukan berarti tanpa kritik. Kajian tim CRCS menyimpulkan bahwa muatan pendidikan agama dalam Kurikulum 2013 memang telah memuat sistematisasi 4 kompetensi inti secara lengkap. Namun, dengan orientasi pendidikan agama yang diajarkan hanya mengajarkan konten satu agama tanpa pengenalan terhadap sudut pandang agama yang berbeda, kecenderungan ini dinilai dapat memperkuat potensi fanatisme sempit dan anti terhadap keragaman budaya dan agama (Suhadi, 2014). Namun demikian, pandangan lain dapat dikemukakan bahwa, meskipun orientasi pendidikan agama di Indonesia itu mono-religion sesuai dengan UU No. 20 Tahun 2003 tentang Sistem Pendidikan Nasional (SPN) Pasal 13, siswa Muslim, Kristiani dan yang beragama lain di jenjang SMP/MTs misalnya, tetap diajari dan dididik dengan prinsip hidup yang toleran dan berintegritas di tengah masyarakat yang plural, yang tentu saja, ditinjau dari sudut pandang agama mereka sendiri. Sebenarnya, sudut pandang mono-religion sebagaimana di Indonesia atau Malaysia di satu sisi; atau multi-religions sebagaimana diterapkan di Eropa di sisi yang lain, bukanlah penentu apakah siswa akan terbiasa dengan nilai-nilai hidup damai. Ini karena yang diperlukan adalah pedagogi atau sistem interaksi di kelas dan yang positif terhadap persamaan dan keragaman hidup (Nurwanto \& Cusack, 2017).

Dilihat dari aspek materi, sebagaimana dalam konseptualisasi Galtung, pendidikan perdamaian tidak hanya mengajarkan 'negative peace' yang bermuatan negasi terhadap bullying, kekerasan atau intimidasi tetapi juga 'positive peace' yang menekankan pada keberlangsungan kondisi masyarakat yang selalu bekerjasama dan proaktif mendukung distribusi keadilan (Bajaj \& Hantzopoulos, 2016). Kehidupan harmoni ini perlu dibangun dari kehidupan sekolah dan kelas secara nyata dengan menempatkan siswa dan guru sebagai subjek yang kritis dan terlibat dalam menciptakan hidup damai. Sementara itu, De Rivera (2009) menunjukkan bahwa ruang lingkup pendidikan perdamaian meliputi: pertama, penerapan dan ketaatan terhadap norma sosial yang terdiri dari kerjasama dan penyelesaianbukan pembiaran - konflik, toleransi dalam keragaman sosial, penanganan permusuhan secara adil serta penghargaan terhadap peran wanita. Kedua, dukungan struktur negara dan peran politik untuk menguatkan partisipasi publik, komunikasi dan akuntabilitas, serta jaminan HAM. Ketiga, advokasi dan pemulihan lingkungan, baik fisik maupun sosial yang meliputi keamanan sosial dan pembangunan berkelanjutan, yang menempatkan prinsip harmoni dengan lingkungan sebagai prioritas. Pendek kata, pendidikan perdamaian mencakup berbagai elemen yang mereduksi konflik dan kekerasan (negative peace), serta menguatkan solidaritas kemanusiaan dan martabat manusia (positive peace). Elemen yang terakhir ini (positive peace) oleh Fox (2014) diyakini sebagai perdamaian yang sesungguhnya.

\section{Kurikulum yang Dipraktekkan (Observed)}

Kurikulum yang direncanakan sebagaimana tertuang dalam Standar Nasional Pendidikan (terutama standar isi), silabus, rencana mengajar, buku ajar dan bahan ajar guru lainnya merupakan satu hal. Ini tidak akan menggambarkan apapun tentang apa dan bagaimana proses interaksi pembelajaran itu berlangsung. Oleh karena itu, kurikulum yang terlaksana di lingkup kelas atau sekolah merupakan pembuktian (evidence-based) tentang aktivitas dan secara khusus bagaimana nilai-nilai toleransi dan perdamaian itu diajarkan. Kurikulum perdamaian yang dipraktekkan di kelas merupakan situasi nyata tentang interaksi siswa, guru, sumber belajar dan lingkungan yang menyertainya untuk mendukung pengetahuan, sikap dan keterampilan hidup damai.

Dilihat dari aspek pedagogik atau proses interaksi pembelajarannya, transformasi hidup damai memerlukan tiga kriteria, yakni konsistensi, kompatibilitas dan koherensi (Nicholson, 2016). Sesuai dengan ruang lingkup pembelajaran hidup damai sebagaimana disajikan oleh Galtung dalam Bajaj and Hantzopoulos (2016) dan De Rivera (2009), target untuk mengurangi pengetahuan, sikap dan perilaku intoleran dan pro-kekerasan di satu sisi dan tumbuhnya kebiasaan kerjasama hidup di sisi yang lain perlu tercermin di dalam teknik dan strategi pembelajarannya. Target bahwa siswa dapat menghargai perbedaan pendapat dengan teman di kelasnya, sebagai contoh, semestinya konsisten dengan teknik belajar siswa melalui presentasi dan diskusi kelompok. Sebagai sebuah teknik mengajar, presentasi atau diskusi dapat dilatih dan dapat dilakukan oleh siswa apabila dibiasakan. Namun demikian, teknik ini perlu dilakukan lebih strategis, yakni dengan mempertimbangkan waktu, tempat dan kondisi untuk menghasilkan outcome (hasil) yang diharapkan. Konsistensi berbagai teknik mengajar untuk menghasilkan outcome misalnya berupa kemampuan menghargai perbedaan sosial (strategi) yang dimulai di ruang kelas pada akhirnya terakumulasi membentuk metode pembelajaran guru. Keseluruhan metode pembelajaran yang teruji dan objektif ini selanjutnya membentuk teori belajar, yang 
dikonstruksi melalui penelitian ilmiah. Apabila frekuensi diskusi dilakukan terus-menerus, maka proses pedagogik tersebut memenuhi kriteria konsistensi. Namun demikian, menurut Nicholson (2016), teknik dan strategi itu harus compatible dengan outcome yang diharapkan. Lebih dari itu, konsistensi dan kompatibilitas yang tinggi merupakan prasyarat ketercapaian prinsip koherensi dari keseluruhan proses dan interaksi pembelajaran di kelas dan sistem nilai yang dibangun di sekolah.

Dalam lingkup praktis ini, siswa diarahkan dapat mengalami hingga menguasai keterampilan hidup damai secara nyata. Fell menjabarkan empat keterampilan yang diperlukan, yakni: afirmasi, komunikasi, kerjasama dan resolusi konflik (Hicks, 1988). Metode pembelajaran diharapkan dapat membangkitkan kemampuan berfikir kritis yang berujung pada kemampuan mendukung sikap respek terhadap sesama serta kemampuan mengutarakan pendapat secara jelas. Tidak hanya itu, kebiasaan bekerjasama juga ditekankan, misalnya melalui cooperative learning di mana siswa merasa bahwa keberhasilan mereka tidak akan tercapai tanpa kehadiran dan bantuan orang lain sehingga mereka terdorong untuk saling berbagi informasi dan penyelesaian masalah (Son, 2019). Konsistensi penerapan cooperative learning dan kompatibilitasnya dengan outcome pembelajaran juga perlu dimonitor. Pada level yang paling penting adalah kemampuan siswa untuk mengutarakan masalah seperti konflik, kemampuan mendengar pihak-pihak yang terlibat konflik, membangun solusi bersama melalui dialog (Guilherme, 2017) dengan pihak-pihak yang terlibat konflik dan diakhiri dengan rekayasa sosial untuk hidup bertenggang rasa. Keterampilan-keterampilan tersebut perlu dibiasakan dalam proses kelas dan sekolah secara luas. Secara praktis, sistem among dalam pembelajaran di Indonesia yang menekankan pada bimbingan dan asuhan yang bersifat kekeluargaan dan natural sehari-hari antara guru dan siswa (Wangid, 2009), misalnya, dapat menjadi model penguatan sistem hidup bersama di sekolah.

Berkaitan dengan proses komunikasi antarpihak, kemampuan yang diperlukan bukan hanya berbicara namun juga kemampuan mendengar dengan empatik. Keterampilan mendengar ini merupakan bagian dari hubungan timbal-balik dalam proses memahami, bernegosiasi dan menemukan solusi. Dengan sangat jelas, Jacobson (2010) menyatakan,

'that kind of deep listening requires a reciprocity in moral education; not only students listening to teachers, but teachers listening to students. Moral education means taking seriously those we educate, living in reciprocal relationships with them. And, again, relationship always requires deep listening ... listening to their 'I like', responding freshly to what they are taking seriously and learning to recognise when we are being bullshitted and when we're not'.

\section{Kurikulum yang Diujikan (Assessed)}

Evaluasi dimaksudkan untuk melihat apakah masih ada gap (kesenjangan) antara apa yang diharapkan dan apa yang telah dicapai siswa, atau sebagaimana Tyler utarakan, berkaitan dengan 'sampai pada kondisi seperti apa level ketercapaian itu' (Stanley, 2009). Dalam pendidikan liberal, pendidikan dibuat terstandar dan terstruktur, di mana target dibuat secara ketat. Siswa-siswa yang tidak mampu 'berkompetisi' maka dengan sendirinya akan tersingkir. Oleh karena itu, sistem evaluasi dibuat serba-kompetitif, hitam-putih dan homogen. Dalam menilai taraf pengetahuan siswa tentang makna penting bekerja sama dengan orang lain misalnya, materi dalam buku teks sebaiknya bukanlah satusatunya ukuran dan jawaban. Begitu juga perkataan (utterance) yang dicatat siswa bukanlah jawaban tunggal dari pertanyaan. Hal yang paling relevan adalah siswa diberi kebebasan untuk mengutarakan pikiran dan pengalamannya, bahkan bisa saja dari pergaulan dengan tetangganya tentang kebutuhan bekerjasama. Jawaban dalam bentuk esai tertulis ataupun ungkapan yang terbuka merupakan jawaban 'autentik' tentang bagaimana kehidupan sehari-hari itu dikonstruk oleh siswa.

Di samping itu, sesuai dengan standar penilaian Kurikulum 2013, ada tiga ranah hasil pembelajaran yang perlu dievaluasi secara simultan, yaitu: pengetahuan, keterampilan dan sikap (Permendikbud No. 16 Tahun 2016). Ketiga ranah ini dapat diuji secara kategorikal namun pada dasarnya tidak terpisah antara satu dengan yang lain. Interaksi dari ketiga ranah tersebut juga kerapkali mencerminkan upaya untuk mencapai tujuan tertentu yang lebih tinggi. Misalnya, peduli atau menjaga lingkungan, baik lingkungan manusia, binatang atau habitat lainnya tidak cukup hanya di level pengetahuan berupa kemampuan menjelaskan berbagai habitat yang perlu dilindungi dan di level sikap seperti ketidaksetujuan terhadap penebangan hutan secara liar. Capaian yang lebih tinggi sebenarnya adalah dalam wujud perilaku (keterampilan) untuk ikut mengubah perilaku buruk yang merugikan lingkungan seperti menembak satwa dan, selanjutnya, terlibat untuk, melakukan penghijauan dan 
perlindungan hewan yang patut dilindungi. Dengan demikian, perilaku atau skills peduli lingkungan adalah tujuan tertinggi sedangkan target lainnya (pengetahuan dan sikap) merupakan 'capaian antara' (intermediary attainment) yang dapat dievaluasi dalam waktu dan tempat yang fleksibel. Respons dan tindakan yang dinamis siswa dalam ikut membangun kehidupan yang harmoni merupakan objek telaah dalam pendidikan perdamaian, bukan jawaban dalam suatu ujian atau tes di dalam waktu tertentu. Oleh karena itu, asesmen pendidikan perdamaian lebih mengutamakan proses yang dinamis, bukan hasil berdasarkan acuan normatif.

\section{Kurikulum yang Dikuasai (Learned)}

Asesmen pada akhirnya menyatakan bahwa siswa telah menunjukan kemampuan tertentu. Namun demikian, ada satu dimensi penting lainnya bahwa apa yang dikuasai siswa sebenarnya bukan dari sekedar apa yang diujikan. Apa yang diujikan oleh sekolah untuk menentukan 'kualitas' siswa dapat saja sebuah 'representasi' kemampuan baik pengetahuan, sikap maupun keterampilan. Namun, di sisi yang lain, ini dapat merupakan 'simplifikasi' atau penyederhanaan dari kemampuan siswa yang kompleks yang tidak dapat dinilai dari suatu sistem evaluasi tertentu. Oleh karena itu, asesmen bukanlah sebuah finalisasi dari penilaian siswa, tetapi ini hanya mencerminkan penilaian sementara yang bersifat relatif.

Sebagaimana jamaknya faktor sosial, apa yang diketahui dan dialami oleh siswa tidak hanya berasal dari kelas dan dari apa yang diajarkan oleh guru dan ditargetkan oleh kurikulum resmi. Siswa juga menyerap informasi dari orang tua, media massa baik cetak maupun elektronik, komunitas dan media sosial seperti sekarang ini. Apa yang dipikirkan dan dirasakan siswa tentang interaksi sosial, baik konflik, kekerasan dan ketegangan emosi di satu sisi, maupun harmoni dan ketenangan hidup di sisi yang lain perlu dijembatani, misalnya melalui kampanye perdamaian dan anti-bullying, penulisan esai tentang kepedulian sosial, kemah perdamaian lintas kelompok, dan berbagai kegiatan ekstra atau sosial lainnya yang mengondisikan siswa untuk menyampaikan gagasan inovatif dan kritis. Atas dasar aktivitas ini, 'apa yang mungkin dikuasai' siswa dapat terekspos dan bahkan menjadi sumber belajar bagi siswa-siswa yang lain.

\section{Kurikulum Tersembunyi (Hidden)}

Kurikulum yang direncanakan adalah bagian dari 'dunia yang diketahui' (the known world) sedangkan pendidikan itu sendiri meliputi juga elemen-elemen yang tidak terjangkau atau tersembunyi (hidden). Makna dan nilai yang melimpah (overwhelming meanings) dari proses pendidikan sebenarnya karena ada yang tidak disadari, baik oleh guru maupun siswa, tetapi ide atau nilai itu mempengaruhi dan membentuk sistem berfikir dan emosi. Darder (2017) mengidentifikasi kurikulum tersembunyi sebagai nilai-nilai sekolah dan cara pandang guru yang secara dominan mempengaruhi sistem belajartermasuk di dalamnya pengetahuan-dan interaksi di sekolah. Sistem nilai tersebut dapat bersumber dari pemahaman dan penghayatan dari budaya, kebiasaan dan kepercayaan yang dianut, sebagaimana dijelaskan Galtung (1990) dalam Standish (2015). Sistem nilai yang telah menyatu (embedded) dalam kehidupan seseorang, baik kekerasan maupun damai, akhirnya membentuk cara pandang dan perilaku keseharian. Sistem keyakinan dan perilaku ini baik sedikit atau banyak tercermin dalam ungkapan dan respons guru terhadap siswa; siswa terhadap guru; dan siswa terhadap siswa lainnya. Sebagaimana ditekankan Standish (2015), sistem nilai yang bersifat simbolik juga mempengaruhi aspek struktur seperti aturan-aturan maupun kultur berupa kebiasaan-kebiasaan di sekolah. Dalam teknis pembelajaran, teknik dan strategi yang dipilih oleh guru juga memuat nilai atau soft skills yang beragam. Sebagai contoh, diskusi secara implisit menciptakan kebiasaan mengungkapkan pendapat, mendengar pendapat orang lain dan melatih menghargai perbedaan. Keterampilan ini terbentuk dengan tanpa disadari oleh subjek belajar. Oleh karena itu, hidden curriculum meliputi aspek yang luas, terentang dari yang abstrak (intangible) seperti keyakinan/ideologi hingga yang konkret (tangible) berupa ungkapan dan perilaku.

Mendasarkan pada konsep kurikulum tersembunyi di atas, pendidikan hidup damai tidak dapat berjalan secara komprehensif bila tidak menyentuh sistem keyakinan dan kebiasaan sehari-hari di sekolah. Kemampuan melakukan respons dan feedback yang spesifik, jelas dan ramah dari seorang guru, kebiasaan berjabat tangan dan senyum sebelum berpisah, menyatakan maaf apabila merepotkan orang lain dan mengungkapkan rasa terima kasih bila diberi kemudahan - untuk menyebut beberapa perilaku positif — dapat menjadi elemen perilaku harian yang tanpa sengaja — karena sudah refleks- 
dapat menciptakan suasana kondusif dan harmonis dalam kehidupan sosial sekolah. Seorang aktivis perdamaian, Irfan Amalee, pendiri Peace Generation Indonesia, membuat ilustrasi sederhana. Ia menulis bahwa bila hendak menilai apakah sekolah itu ramah anak (child friendly) atau tidak; atau mendeteksi apakah visi keramahan sekolah itu nyata atau tidak; cukup dengan menyaksikan respons pertama yang pengunjung rasakan ketika bertemu staf di pintu gerbang sekolah. Pernyataan ini terkesan simplistik namun sebenarnya pesannya adalah bahwa nilai dominan apa yang ada di sekolah itu dapat dilihat dari kebiasaan harian yang sederhana dan nyata (daily real life). Oleh karena itu, konstruksi aturan dan pelaksanaan kurikulum formal tidak akan berkembang bila sistem nilai, baik yang nyata ataupun tersembunyi tidak hidup menjadi sikap dan perilaku di antara para pihak yang terlibat dalam dunia sekolah.

\section{SIMPULAN}

Di tengah fakta kekerasan siswa, sekolah perlu merumuskan sistem pendidikan yang selaras dengan pendidikan perdamaian. Pendidikan perdamaian yang dimaksud melingkupi dua aspek. Pertama adalah komitmen sumber daya dan proses kurikulum yang mampu mengantisipasi dan mencegah sikap dan tindakan kekerasan dan konflik di antara warga belajar. Kedua adalah proses pembelajaran yang memungkinkan sikap saling menghormati atas perbedaan, praktik dialog dan kerjasama dapat berlangsung secara berkesinambungan dalam proses pembelajaran dan interaksi keseharian di sekolah. Agar tidak sekadar formalitas, pendidikan perdamaian perlu dikonstruk dari hulu hingga hilir melalui kurikulum yang bersifat multidimensional. Karena sekolah sebagai sistem belajar yang kompleks, kurikulum perlu ditempatkan dalam dinamika dan proses persekolahan itu sendiri. Kurikulum yang kerapkali ditempatkan sebagai materi ajar yang sudah direncanakan, perlu diperluas dimensinya sebagai ruang lingkup pengalaman yang terpadu. Dimensi kurikulum berupa elemen pembelajaran yang direncanakan, proses pembelajaran secara nyata di kelas, sistem evaluasi dan sistem sosial yang memberi ruang ekspresi pengetahuan dan pengalaman siswa juga perlu diwujudkan. Selain itu, berbagai sistem simbolik dan nilai yang tersembunyi melalui aturan sekolah dan interaksi guru dan siswa juga perlu konsisten, kompatibel dan koheren dengan pengetahuan, sikap dan perilaku hidup damai yang diajarkan. Melalui pendekatan holistik atas kurikulum ini, sekolah diharapkan dapat menjadi ranah nyata untuk penyemaian perdamaian.

\section{DAFTAR PUSTAKA}

Al Qurtuby, S. (2016). Religious Violence and Conciliation in Indonesia: Christians and Muslims in the Moluccas. London: Routledge.

Alkin, M. C. (1992). Encyclopedia of educational research (Vol. 3). USA: Macmillan.

Amin, E. (2015). Reclaiming Jihad: A Qur'anic Critique of Terrorism. England: Kube Publishing Ltd.

Ardizzone, L. (2001). Towards global understanding: The transformative role of peace education. Current issues in comparative education, 4(1), 1-10.

Arweck, E., \& Nesbitt, E. (2008). Peace and non-violence: Sathya Sai education in human values in British schools. Journal of Peace Education, 5(1), 17-32.

Bajaj, M., \& Hantzopoulos, M. (2016). Peace education: International perspectives: Bloomsbury Publishing.

Bar-Tal, D. (2002). The elusive nature of peace education. Peace education: The concept, principles, and practices around the world, 27-36.

BPS. (2014). Statistik Kriminal 2014. Jakarta: BPS.

Darder, A. (2017). Reinventing Paulo Freire: A Pedagogy of Love. London: Routledge.

Davies, L. (2005). Schools and war: Urgent agendas for comparative and international education. Compare: A Journal of Comparative and International Education, 35(4), 357-371.

Davies, L. (2009). Educating against Extremism. England: Trentham Books. 
Penyemaian Sikap Hidup Damai di Sekolah: Tinjauan Pendidikan Perdamaian dan Multi-Dimensi

Kurikulum (Nurwanto, Wahdan Najib Habiby)

De Rivera, J. (2009). Assessing the peacefulness of cultures. In Handbook on Building Cultures of Peace (pp. 89-103). Singapore: Springer.

Djamal, M. (2016). Fenomena Kekerasan di Sekolah. Yogyakarta: Pustaka Pelajar.

Fox, M. A. (2014). Understanding Peace: A Comprehensive Introduction. New York: Routledge.

Guilherme, A. (2017). Understanding conflict resolution philosophically in a school setting: three different kinds of violence and dialogue. Journal of Peace Education, 14(2), 215-234.

Harber, C. (2002). Schooling as violence: An exploratory overview.

Harber, C. (2008). School, Violence and Peace Education. In Encyclopedia of Peace Education. Columbia: Columbia University.

Harber, C., \& Sakade, N. (2009). Schooling for violence and peace: How does peace education differ from 'normal'schooling? Journal of Peace Education, 6(2), 171-187.

Harris, I. M., \& Morrison, M. L. (2012). Peace Education. USA: McFarland.

Hergianasari, P. (2019). Konsep Deradikalisasi Pada Pendidikan Berbasis Pembelajaran Terpadu. Scholaria: Jurnal Pendidikan dan Kebudayaan, 9(3), 239-244.

Hicks, D. (1988). Education for peace: Issues, principles, and practice in the classroom. USA: Taylor \& Francis.

Jacobson, R. B. (2010). On bullshit and bullying: taking seriously those we educate. Journal of Moral Education, 39(4), 437-448.

Kadir, H. A. (2012). School gangs of Yogyakarta: Mass fighting strategies and masculine charisma in the city of students. The Asia Pacific Journal of Anthropology, 13(4), 352-365.

Kelly, A. V. (2009). The curriculum: Theory and practice. London: Sage.

Khan, V. (2009). The Prophet of Peace: Teachings of the Prophet Muhammad. India: Penguin Books.

Köylü, M. (2004). Peace education: an Islamic approach. Journal of Peace Education, 1(1), 59-76.

Lewsader, J., \& Myers-Walls, J. A. (2017). Developmentally appropriate peace education curricula. Journal of Peace Education, 14(1), 1-14.

Mirbagheri, S. F. (2012). War and Peace in Islam: A Critique of Islamic/ist Political Discourses. England: Springer.

Munawar-Rachman, B., \& Shofan, M. (2015). Pendidikan karakter: pendidikan menghidupkan nilai untuk pesantren, madrasah, dan sekolah. Jakarta: Paramadina.

Muryanto, B. (2017, 5 April). Yogyakarta sees rising violence among youths. The Jakarta Post. Retrieved from https://www.thejakartapost.com/news/2017/04/05/yogyakarta-seesrising-violence-among-youths.html

Nicholson, D. W. (2016). Philosophy of Education in Action: An Inquiry-based Approach. New York: Routledge.

Nilan, P., Demartoto, A., \& Wibowo, A. (2011). Young men and peer fighting in Solo, Indonesia. Men and masculinities, 14(4), 470-490.

Nurwanto, \& Cusack, C. M. (2017). Addressing multicultural societies: lessons from religious education curriculum policy in Indonesia and England. Journal of Religious Education, 64(3), 157-178.

Nurwanto, N., Azhar, M., Marsudi, M., \& Ismail, G. (2015). Nilai-Nilai Perdamaian dalam Buku Teks Pendidikan Agama Islam (Akhlak) di Sekolah Muhammadiyah. Afkaruna: Indonesian Interdisciplinary Journal of Islamic Studies, 11(1), 41-65.

Pollard, A., Black-Hawkins, K., Cliff-Hodges, G., Dudley, P., \& James, M. (2014). Reflective Teaching in Schools: Evidence-Informed Professional Practice. London: Bloomsbury Publishing. 
Purwawidada, F. (2014). Jaringan Baru Teroris Solo. Jakarta: PT Gramedia.

Rakhmat, M. Z., \& Tarahita, D. (2018, 22 February). Violence in Indonesia's Schools. Asia Sentinel.

Saad, H. M. (2003). Perkelahian Pelajar: Potret Siswa SMU di DKI Jakarta. Yogyakarta: Galangpress Group.

Son, R. S. S. (2019). Pengaruh Model Pembelajaran Kooperatif Tipe Time Token Terhadap Hasil Belajar Siswa SMP. Scholaria: Jurnal Pendidikan dan Kebudayaan, 9(3), 284-291.

Standish, K. (2015). Cultural Violence in the Classroom: Peace, Conflict and Education in Israel. UK: Cambridge Scholars Publishing.

Stanley, A. F. (2009). The Tyler Rationale and the Ralph Tyler Project: an Historical Reconsideration. University of Georgia,

Suhadi, e. a. (2014). Politik Pendidikan Agama Kurikulum 2013 dan Ruang Publik Sekolah. Yogyakarta: Center for Religious \& Cross-cultural Studies.

UNICEF. (2017). A Familiar Face: Violence in the Lives of Children and Adolescents. New York: UNICEF.

Wangid, M. N. (2009). Sistem among pada masa kini: Kajian konsep dan praktik pendidikan. Jurnal Kependidikan: Penelitian Inovasi Pembelajaran, 39(2).

Yasin, M., \& Perdana, H. (2014). Panduan Bantuan Hukum di Indonesia. Jakarta: Yayasan Obor Indonesia. 